Acta Poetica 27 (2)

OTOÑO

2006

\title{
Palabras en el aire
}

\author{
Perla Sneh
}

Las palabras no son inocentes cuando hablamos del exterminio. Heredamos las palabras de los muertos pero también las de los perpetradores y con ellas debemos hablar. ¿Cómo hacerlo si el lenguaje declina su responsabilidad para volverse jerga universitaria o intelectualismo vacío?

Words are not innocent. We inherit the words of the dead but also those of the perpetrators and with these words we must keep on talking. How can we do that when language declines his responsibility and becomes academic gibberish or empty intelectualism? 

Perla Sneh

Universidad de Buenos Aires, República Argentina

\section{Palabras en el aire}

Más que a nada, el hombre está abierto al aire Elías Canetti

\section{Las mejores intenciones}

Hablar, lo sabemos, es un dilema ético, pero saberlo no lo vuelve menos opaco. A la hora de las palabras hay quienes confían en un saber que permita, al abordar la generalidad de un concepto, proceder a su explicación con miras a su resolución. Hay quienes confían en una férrea, rigurosa, moral que venga a poner orden en los acontecimientos. Hay quienes confían en la historia que, al incorporar un hecho a su dialéctica, le daría aquella precisa, exacta, inscripción que impediría su retorno.

No hay por qué cuestionar tanta confianza, pero es mejor abstenerse de entusiasmarnos demasiado. A veces conviene disponernos a hablar y entonces, al escucharnos, enterarnos de lo que decimos. Si en algo es pertinente una consideración psicoanalítica de la pregunta que nos convoca ${ }^{1}$ es en el intento

${ }^{1}$ Este texto surge de la ponencia leída en la mesa de cierre del Primer Encuentro Internacional Análisis de las Prácticas Sociales Genocidas - “¿Por qué hablar de 
de ubicar a dónde van a parar las palabras. Hay cosas que retornan — viene a decir el psicoanálisis - y lo hacen en los lugares más imprevistos. Hablar nos ubica, entonces, en lo provisorio de una palabra que nunca sabe bien a dónde va; aunque no por eso dejamos de decirla.

Genocidio: el término tienta al vértigo de la imagen, a la desmesura cuantitativa, a la impudicia de una cámara pródiga en materia cadavérica, a las estridencias ominosas de la información, de la esgrima ideológica. Pero hablamos — creo- de nuestros muertos, ¿por qué nombrarlos con esa muerte industrial, sistemática, acumulable, precisamente aquella que los despoja de su nombre?

Sí, dije nuestros muertos: no se me escapa el problema que plantea esta difícil propiedad. Pero en todo caso, también sabemos — a pesar de toda corrección política— que los muertos no son todos iguales.

En mi infancia, los muertos hablaban ídish, a veces polaco o ruso, pero cada uno contaba la interminable y muda narración del exterminio. Si algo definía esas lenguas — que eran de mis padres y también mías - era esa rara aptitud para narrar la matanza, el crujido insomne de las consonantes, el acorde letánico de las vocales, el latido inquieto —inquietantede las voces extranjeras.

Con el tiempo, la lengua de los argentinos — que es la mía y un poco la de mis padres, pero también la de mis hijosaprendió a decir "campos de concentración", "traslado", "solución final" por impulso propio: las palabras que habían contado la vida judía bajo el nazismo — la muerte judía- contaban ahora la agonía argentina bajo la dictadura. Los muertos aprendieron a hablar castellano y las voces se fueron atra-

genocidio hoy?"-, realizado en Buenos Aires entre el 10 y el 15 de noviembre de 2003 y convocado por la Facultad de Ciencias Sociales de la Universidad de Buenos Aires junto con el Instituto de Artes y Ciencias de la Diversidad Cultural de la Universidad Nacional de Tres de Febrero. 
gantando con las astillas de un destruido mito de inocencia esencial.

¿Qué hubo en el medio? Podemos decir: la historia. Pero quizás haya que decir también: los modos de una memoria que va tramándose en torno a la lengua de los muertos.

En 1945, 46, 47, la memoria de la Shoá apenas figuraba; los juicios de Nürnberg, los ajustes de cuentas entre Estados (victoriosos o vencidos, pero soberanos) no tenían lugar para los judíos, ellos (quiero decir, nosotros) — cuerpos escamoteados al exterminio - no pesaban en esa memoria. Pero recuerdos había. En 1963 un Estado soberano emite una orden de detención en hebreo y logra llevar a juicio a Adolf Eichmann. Para eso debió vulnerar el derecho de otro Estado, casualmente el argentino, secuestrar a uno de sus ciudadanos, sacarlo clandestinamente del país y hacerlo comparecer ante una corte extranjera. La historia - al menos la nuestra - guarda registro del debate público, no poco virulento, mucho más centrado en los derechos del individuo que en los crímenes del asesino. Pero entonces, hoy, con todo lo que ha corrido bajo el puente, ¿no podríamos pensar que los problemas que plantea al derecho argentino el principio de extraterritorialidad — que permitiría la aplicación de leyes penales extranjeras a ciudadanos argentinos por jueces de otros países- es un modo en que nos retorna el asunto Eichmann?

Pero volvamos a - si es que alguna vez nos fuimos de- la lengua de los muertos. Decíamos que las palabras que contaban la historia judía comenzaron a decir la experiencia argentina: el subversivo devino un enemigo interno, insidioso y, por tanto, cuerpo prometido a la destrucción, como el judío bajo el nazismo. También empezamos a hablar de una diáspora argentina constituida en torno al exilio político, una diáspora que pasó a ser "un distintivo nacional, una marca de fábrica". ${ }^{2}$

${ }^{2}$ Bonasso 1994. 
Y también, al igual que la Shoá, algo de la historia argentina se abismó en una crisis de representación.

Solución final: la cosa estaba, como se dice, en el aire, en la materia misma de la palabra, materia cruzada por el rastro transparente e indeleble de los que "pasaron del estado de Luftmensch al de Luft", ${ }^{3}$ ahí donde las cenizas habían cavado su tumba en las nubes, ${ }^{4}$ en ese fulgor de moléculas transparentes hendido por la estela de los cuerpos cayendo a un río "que nada devolverá, que se quedará con todo".

Hablar es agitar ese aire donde la cosa estaba, acelerar sus moléculas; alborotarlo, tragarlo, expelerlo en un espasmo de tos o de risa, echarlo de menos, quedarse sin él. Ese aire donde reverbera la huella evanescente de los cuerpos sustraídos es lo que manoseamos con cada letra pronunciada. El aire, dirá Elías Canetti, esa cosa común - la única cosa en común que nos queda- que nos envenenará, eventualmente, a todos, aun sin que lo notemos.

En un homenaje a Hermann Broch, Canetti le atribuye ${ }^{5}$ lo que llama el arte de la respiración, del que carecemos y que, según él, Broch erige en política de escritura. Canetti añora esa política — que permite denunciar la asfixia varios años antes de la construcción de la primera cámara de gas- y pone la lucidez de su escritura a cuenta de lo que llama "memoria respiratoria", una peculiar memoria hecha de imágenes respiratorias que, en contraposición a las imágenes cromáticas del pintor y dado el cercano parentesco entre respiración y palabra, se realizan en la lengua.

Hoy, lo irrespirable es imagen de esa memoria respiratoria que ahora nos alcanza y nos insufla el aire de los muertos. No es raro, entonces, que nos quedemos sin aliento, porque en lo

\footnotetext{
${ }^{3}$ Schwarz-Bart 1959.

${ }^{4}$ Véase el poema "Fuga de Muerte", de Paul Celan, en Celan 2002.

${ }^{5}$ Canetti 1994.
} 
irrespirable del aire que removemos, como dice Celan, cualquier palabra que pronuncies / estás agradeciendo / la destrucción.

Advertencia para los vivos, que también hablan - hablamos-. Pero entonces hay que decir que tampoco los vivos son - somos - todos iguales y que esa diferencia se labra en el lugar donde cada uno se encuentra cuando habla.

¿Cómo habla el que habitó el abismo y retorna a la minucia cotidiana? ¿Cómo habla el sobreviviente si con él sobrevive el exterminio? ¿Cómo habla el que no fue padre o hijo o heredero directo de la matanza? ¿Cómo habla alguien que no es (nunca lo fue, nunca podría serlo) uno de ellos pero que no sabría ubicar un sujeto si se propusiera uno de nosotros? ¿Aquel que no se quedó en su casa (sencillamente porque casa - lo que se dice casa - no había para nadie, aunque sí hubiera frente de donde faltar) pero no fue a ningún lado? ¿O ese que somos nosotros, ahora, aquí sentados, nosotros, los impuntuales a la hora de la matanza? ¿O aquel que seguramente no era parte de ellos, pero que dio en adherir a un extraño nosotros como lo hicieron, por ejemplo, aquellos que al tanto - por experiencia propia o ajena- de lo que ocurría en chupaderos y centros clandestinos hablaban de nuestras Fuerzas Armadas en los días primeros de la desesperante empresa de Malvinas?

Inquietante solicitación de la lengua, inquietante solicitación de gestos, palabras y silencios que, desde "deme dos" al "en algo andaría", 6 tramaba la red de negaciones y compulsas que demandaba la convivencia con lo siniestro, la resbalosa rampa que va de la pasividad al consentimiento, del silencio a la colaboración.

${ }^{6}$ Expresiones comunes en los años de la dictadura en la Argentina (19761983) que indicaban la indiferencia — por momentos rayana en la complicidadante la desaparición de personas ("en algo andarían" o "por algo será") como la irresponsable aceptación de un ficticio bienestar financiero que desembocó en un desastre económico para el país ("déme dos”, expresión que solían repetir los argentinos comprando electrodomésticos en Miami). 
Modos y modos y modos de decir. El aire acecha, imposible no irse de boca: cualquier vibración, cualquier constelación de moléculas, cualquier palabra ya es agradecer la destrucción. ¿Habrá que preguntarse entonces cómo hacer para hablar menos? ¿O habrá que decir que hablamos - y que no queremos dejar de hacerlo- aun si nuestras palabras conllevan la envenenada gracia de la destrucción?

\section{Las peores palabras}

¿En qué yace la singularidad de cada uno de esos acontecimientos asesinos que denominamos genocidio? David Bankier, ${ }^{7}$ historiador, estudioso de la Shoá, propone: ni en el sufrimiento de la víctima, ni en la pasividad del testigo, ni en la indiferencia del conciudadano, sino en la motivación del perpetrador. Pero acá las cosas se oscurecen.

En los testimonios aparecidos inmediatamente después de la segunda Guerra Mundial, el perpetrador aparece como una figura brutal, sádica, feroz. Diez años más tarde —una vez juzgado Eichmann y editada ya La banalidad del mal de $\mathrm{H}$. Arendt- el perpetrador se transforma en el burócrata que elimina trivialmente a sus víctimas. En los últimos años ha surgido una figura más inquietante aún, al menos para nosotros, los así llamados intelectuales.

Un estudio hecho sobre el servicio de inteligencia del Reich (RSHA) revela que al menos el $20 \%$ de sus tres mil empleados, dedicados todos a la administración de la muerte, no eran "sádicos", pero tampoco meros "burócratas". Estos empleados, en su mayoría graduados universitarios, ante la pregunta sobre qué los motivó a dedicarse a estas tareas suelen invocar el más elevado idealismo. Se trataba de abogados, historiadores, juristas,

\footnotetext{
${ }^{7}$ Bankier 2002.
} 
expertos en literatura, que eligieron participar en lo que consideraron una gran empresa de reestructuración del mundo. Egresados de Medicina que tuvieron la oportunidad de no ser un médico más en un hospital y se fueron a hacer biología al Este. Egresados de Filosofía que, en vez de discurrir sobre el Estado ideal, entraron en los campos de concentración para construir su propia República ideal. Juristas que modelaban la figura jurídica perfecta que corresponde a un pueblo de Herren (amos). ${ }^{8}$ Werner Best, asesor legal de la Gestapo, dedicó su pensamiento a sostener la divisa de toda una concepción de la cultura política que floreció en los años del ascenso del Reich: aprender a matar sin odio. ${ }^{9}$

Podríamos discutir aquí varias cosas, la denominación de "idealismo", ${ }^{10}$ la noción de figura del perpetrador, el recurso a la prosopografía ("biografía colectiva") necesaria para establecer estos motivos, pero me interesa más detenerme en un detalle en apariencia menor: ¿qué preguntas se hicieron para conformar estos informes? ¿Cómo fue posible esa conversación?

¿Es posible escuchar la cotidianidad de las palabras asesinas? Porque la hubo, hubo una pedagogía del horror, hubo palabras específicas para establecer modos y procedimientos, alcances, manejos. ¿Rige en esa habla la crisis de la representación? ¿Irrumpe allí lo indecible? ¿Cómo habla eso? La pregunta no es ociosa, porque eso permanece ahí —aquí- presente y mudo. Porque entre nosotros, en el aire que respiramos, resuenan las palabras eficaces, las voces que no vacilaron; permanecen

${ }^{8}$ Bankier 2002.

${ }^{9}$ Ya en los comienzos del nazismo, la quema de libro de mayo de 1933 fue organizada por la Liga Estudiantil Alemana (Deutsche Studentenschaft) — semillero de los mencionados integrantes de la RSHA - contra libros "contrarios al espíritu alemán”. Participaron rectores, profesores y estudiantes universitarios, juntos con las SA y las Juventudes Hitlerianas.

${ }^{10}$ Bankier 2002. Mas precisamente, Bankier lo llama "idealismo nazi perverso", nombre que - por su referencia al concepto de perversión- requeriría una discusión que excede los márgenes de este trabajo. 
las miradas que no parpadearon. ¿Con qué términos se trama la peor conversación posible? También ahí hay un tortuoso, sofocante e improbable trabajo de la memoria: encontrar las palabras que algunos pudieron decir, hacer, saber, sin atragantarse al decirlo, hacerlo o saberlo.

Intentar las peores preguntas, las más irrespirables. Pero entonces habrá que ser cuidadosos, el aire se vuelve malsano. Porque el habla cotidiana de los asesinos es sólo un modo extremo de relato escamoteado. ¿Qué hay del relato de los "intelectuales" de la violencia? Los egresados de Filosofía, de Medicina, los expertos en literatura, ¿con qué palabras hablaban? ¿Qué leían? ¿Qué elucubraban? ¿Cuánto aportaron a la "ilustración" de la "gente"? ¿Cuánto a la trama sostenida en torno a la idea de depuración, la pureza, el orden de esa Argentina que — ¡tantos coincidían en ello! — había que limpiar? ¿Cuánto a la "modernidad terminológica" que tanto advenía exigencia de "claridad" como jerga de suplemento dominical? ¿Cuánto aportan estos aportes a la memoria encorsetada en oferta de olvido colectivo?

¡Ah!, pero cuestionar eso es cuestionarse uno mismo, es ir en busca del propio rastro, la propia voz en el aire. ¿Cómo hablar las peores palabras y no envenenarnos con ellas? ¿Cómo pensarnos nosotros como una voz en esa memoria que exige polifonía? Ese nosotros puede querer decir: los que no estamos muertos, es decir los que aun tenemos algo que decir. Incluso si sólo nos quedan esas palabras, las peores, las más venenosas o las más envenenadas, para interrogarse por la matanza o por la civilización por la improbable posibilidad de una política que no se reduzca a la ferocidad binaria de un ellos ante un nosotros.

Habrá que buscar el modo de sostenerse en la falta de respuesta, de arremeter cuando la razón abandona, de vacilar en la osadía del intento. Habrá que buscar el tono: yo sospecho que es en voz baja, porque hay que dosificar el aire, aprender 
a respirar. Es preciso ser cuidadosos, mesurados. Porque retomar el relato de los muertos con la lengua de los vivos siempre puede dejarnos boqueando: se trata de hablar en ese aire denso. Y nadie sabe si no habrá que respirar hondo y hundirse de una buena vez.

\section{REFERENCIAS}

Bankier, David, 2002. "La Shoá y los genocidios del siglo xx", conferencia dictada el 7 de agosto de 2002 en la Fundación Memoria del Holocausto, Revista Fundación Memoria del Holocausto, 20, Buenos Aires.

Bonasso, Miguel, 1994. Recuerdo de la muerte, Buenos Aires, Planeta. Canetti, Elías, 1994. La conciencia de las palabras, 2-a reimpresión, México, FCE.

Celan, Paul, 2002. Obras completas, traducción de José Luis Reina Palazón, prólogo Carlos Ortega, Madrid, Trotta.

Schwarz-Bart, André, 1959. El último justo, Barcelona, Seix Barral. 